\title{
Pengaruh Independensi Auditor, Pemahaman Good Governance dan Self Efficacy Terhadap Kinerja Auditor Pada KAP Bali
}

\author{
Ida Bagus Widya Kirana ${ }^{1}$ \\ H. Bambang Suprasto ${ }^{2}$ \\ ${ }^{1,2}$ Fakultas Ekonomi dan Bisnis Universitas Udayana (Unud), Bali, Indonesia \\ e-mail: ib.adinata@gmail.com
}

\begin{abstract}
ABSTRAK
Penelitian ini bertujuan untuk meneliti pengaruh Independensi auditor, pemahaman good governance dan self efficacy pada kinerja auditor. Penelitian ini dilakukan pada Kantor Akuntan Publik di Bali tahun 2018. Jumlah sampel yang diambil 69 auditor yang bersedia berpartisipasi dalam penelitian ini. Sampel dalam penelitian ini ditentukan dengan metode purposive sampling. Data dikumpulkan dengan menggunakan metode survey. Teknik analisis data yang digunakan adalah analisis Regresi Linier Berganda dan Moderated Regression Analysis (MRA). Penelitian ini berhasil menunjukkan independensi auditor dan pemahaman good governance berpengaruh positif terhadap kinerja auditor. Penelitian ini juga menunjukan bahwa self efficacy berpengaruh positif terhadap kinerja auditor. Hal ini menunjukan jika seorang auditor yang memiliki independensi, pemahaman good governance dan self efficacy yang tinggi maka akan mempengaruhi kinerjanya.

Kata kunci: Independensi auditor, pemahaman good governance, self efficacy, kinerja auditor
\end{abstract}

\begin{abstract}
This study aims to examine the effect of auditor independence, understanding good governance and self efficacy on auditor performance. This research was conducted at the Public Accountant Office in Bali in 2018. The number of samples taken was 69 auditors who were willing to participate in this study. The sample in this study was determined by purposive sampling method. Data is collected using survey methods. The data analysis technique used is the analysis of Multiple Linear Regression and Moderated Regression Analysis (MRA). This study successfully showed auditor independence and understanding of good governance had a positive effect on auditor performance. This study also shows that self efficacy has a positive effect on auditor performance. This shows that if an auditor who has independence, understanding good governance and high self efficacy will affect his performance.

Keywords: Auditor independence, understanding of good governance, self efficacy, auditor performance
\end{abstract}

\section{PENDAHULUAN}

Perkembangan dunia usaha yang semakin pesat sekarang ini dapat memicu persaingan yang semakin meningkat diantara pelaku bisnis. Berbagai macam usaha dilakukan untuk meningkatkan pendapatan dan agar tetap bertahan dalam menghadapi persaingan tersebut, terus dilakukan oleh para pengelola perusahaan. 
Ida Bagus Widya Kirana dan H. Bambang Suprasto. Pengaruh ...

Salah satu kebijakan yang sering ditempuh oleh pihak perusahaan adalah dengan melakukan pemeriksaan laporan keuangan oleh pihak ketiga yang independen, dalam hal ini akuntan publik. Manajemen perusahaan memerlukan jasa pihak ketiga agar pertanggungjawaban keuangan yang disajikan kepada pihak luar dapat dipercaya, sedangkan pihak luar perusahaan memerlukan jasa pihak ketiga untuk memperoleh keyakinan bahwa laporan keuangan yang disajikan oleh manajemen perusahaan dapat dipercaya sebagai dasar keputusan yang diambil oleh mereka (Mulyadi, 2014:3).

Kalbers dan Forgatty (1995) (dalam Trisnaningsih (2007)), mengemukakan bahwa kinerja auditor sebagai evaluasi terhadap pekerjaan yang dilakukan oleh atasan, rekan kerja, diri sendiri, dan bawahan langsung. Dari pengertian tersebut, dapat disimpulkan bahwa kinerja auditor adalah suatu hasil kerja yang dicapai oleh seseorang auditor dalam melaksanakan tugas-tugas yang dibebankan kepadanya yang didasarkan atas kecakapan, pengalaman, dan kesungguhan waktu yang diukur dengan mempertimbangkan kuantitas, kualitas, dan ketepatan waktu. Auditor dalam melaksanakan pemeriksaan akuntan, memperoleh kepercayaan dari klien dan para pemakai laporan keuangan untuk membuktikan kewajaran laporan keuangan yang disusun dan disajikan oleh klien. Klien dapat mempunyai kepentingan yang berbeda, bahkan mungkin bertentangan dengan kepentingan para pemakai laporan keuangan. Demikian pula, kepentingan pemakai laporan keuangan yang satu mungkin berbeda dengan pemakai lainnya. Oleh karena itu, dalam memberikan pendapat mengenai kewajaran laporan keuangan yang 
diperiksa, auditor harus bersikap independen terhadap kepentingan klien, pemakai laporan keuangan, maupun kepentingan auditor itu sendiri.

Kinerja dari profesi auditor independen saat ini sedang mendapatkan sorotan tajam bahkan sinis dari masyarakat umum akibat terjadinya skandal-skandal besar di negara maju dan berkembang seperti Amerika Serikat dan di Indonesia. Pertama Kasus Enron dan Kantor Akuntan Publik (KAP) Arthur Andersen yang sudah melanggar kode etik yang seharusnya menjadi pedoman dalam melaksanakan tugasnya dan bukan untuk dilanggar, karena perbuatan mereka inilah, keduanya menuai kehancuran dimana Enron bangkrut dengan meninggalkan hutang milyaran dolar, sedangkan KAP Arthur Andersen kehilangan keindependensiannya dan kepercayaan dari masyarakat terhadap kinerja KAP tersebut, juga berdampak pada karyawan yang bekerja di KAP Arthur Andersen (Santoso, 2002).

Di Indonesia kasus yang serupa pernah terjadi yang melibatkan Kantor Akuntan Publik (KAP) Drs Tahrir Hidayat dan Akuntan Publik (AP) Drs Dody Hapsoro yang melakukan pelanggaran terhadap Standar Profesional Akuntan Publik (SPAP) dalam pelaksanaan audit atas Laporan Keuangan konsolidasi PT Pupuk Sriwidjaya (Persero) dan anak perusahaan tahun buku 2005 (Sitio, 2014). Karena pelanggaran yang dilakukan, Kantor Akuntan Publik (KAP) Drs Tahrir Hidayat dan Akuntan Publik (AP) Drs Dody Hapsoro mendapatkan sanksi berupa pembekuan ijin atas pelaksanaan jasa audit serta hilangnya kepercayaan masyarakat terhadap keindependensian dari akuntan publik tersebut. Dan diharapkan kejadian seperti ini tidak terjadi lagi dan diharapkan juga para auditor 
independen dapat lebih hati-hati dan lebih teliti lagi dalam mengadakan pemeriksaan terhadap perusahaan yang diauditnya dan tetap menjaga prinsipprinsip dan kode etik profesi akuntan independen. Kasus-kasus di atas tersebut telah memerlihatkan bahwa dalam mewujudkan KAP yang berkualitas dan profesional sangat ditentukan oleh kinerja auditornya, karena semakin meluasnya kebutuhan jasa profesional akuntan publik sebagai pihak yang dianggap independen, maka akan menuntut profesi akuntan publik untuk terus meningkatkan kinerjanya agar dapat menghasilkan produk audit yang dapat diandalkan bagi pihak yang membutuhkan (Herawaty \& Susanto, 2009).

Berhasil tidaknya kinerja auditor yang telah dicapai organisasi tersebut dipengaruhi oleh tingkat kinerja auditor secara individu maupun kelompok. Ristio et al. (2014) (dalam Arianti (2015)) menyatakan, kinerja auditor merupakan hasil dari kerja auditor dalam melaksanakan tugasnya sesuai dengan tanggung jawab auditor tersebut. Kinerja (prestasi kerja) dapat diukur melalui pengukuran tertentu (standar), dimana kualitas adalah berkaitan dengan mutu kerja yang dihasilkan, sedangkan kuantitas adalah jumlah hasil kerja yang dihasilkan dalam kurun waktu tertentu, dan ketepatan waktu adalah kesesuaian waktu yang telah direncanakan (Trisnaningsih, 2007). Auditor yang memiliki kinerja yang baik dapat dinilai dari peningkatan kualitas audit yang terlihat dari ketepatan strategi dan kebijakan yang diambil manajer perusahaan (Rangkuti, 2008).

Larkin (1990) (dalam Trisnaningsih (2007)) menyatakan bahwa terdapat empat dimensi personalitas dalam mengukur kinerja auditor, yaitu kemampuan (ability), komitmen profesional, motivasi, dan kepuasan kerja. Seorang auditor 
yang mempunyai kemampuan dalam hal auditing maka akan cakap dalam menyelesaikan pekerjaan. Auditor yang komitmen terhadap profesinya maka akan loyal terhadap profesinya seperti yang dipersepsikan oleh auditor tersebut. Motivasi yang dimiliki seorang auditor akan mendorong keinginan individu auditor tersebut untuk melakukan kegiatan-kegiatan tertentu untuk mencapai tujuan. Kepuasan kerja auditor adalah tingkat kepuasan individu auditor dengan posisinya dalam organisasi secara relatif dibandingkan dengan teman sekerja atau teman seprofesi lainnya.

Faktor-faktor yang memengaruhi kinerja Sumber Daya Manusia (SDM) menurut para ahli diantaranya; Simamora (1995) menyatakan kinerja dipengaruhi oleh tiga faktor yaitu faktor individu, faktor psikologis dan faktor organisasi. Wirawan (2009) juga menjelaskan bahwa kinerja SDM merupakan hasil sinergi dari tiga faktor, yaitu faktor internal karyawan, faktor internal organisasi dan faktor eksternal, sedangkan menurut Davis 1989 (dalam Mangkunegara (2010)), faktor yang memengaruhi pencapaian kinerja SDM adalah kemampuan (ability) dan faktor motivasi (motivation).

Kinerja auditor sangat dipengarhi oleh independensi yang dimiliki oleh seorang auditor. Independensi merupakan standar umum nomor dua dari tiga standar auditing yang ditetapkan oleh Ikatan Akuntan Indonesia (IAI) yang menyatakan bahwa dalam semua hal yang berhubungan dengan penugasan, independensi dalam sikap mental harus dipertahankan oleh auditor. Artinya auditor seharusnya berada dalam posisi yang tidak memihak siapapun karena ia melaksanakan pekerjaanya untuk kepentingan umum. Independensi dapat juga 
Ida Bagus Widya Kirana dan H. Bambang Suprasto. Pengaruh ...

diartikan adanya kejujuran dalam diri auditor dalam mempertimbangkan fakta dan adanya pertimbangan yang obyektif tidak memihak dalam diri auditor dalam merumuskan dan menyatakan pendapatnya (Mulyadi, 2002).

Auditor yang memiliki independensi yang baik cenderung memiliki kesan yang baik di masyarakat sehingga auditor tersebut senantiasa menjaga kinerjanya dalam melakukan tugas audit, hal ini disebabkan karena pelayanan jasa akuntan sangat dipengaruhi oleh kepercayaan klien maupun publik secara luas dengan berbagai macam kepentingan yang berbeda (Trisnaningsih, 2007). Seorang auditor yang memiliki independensi tinggi maka kinerjanya akan menjadi lebih baik. Penelitian Awaluddin (2017) yang sejalan dengan penelitian Arifah (2012) tentang pengaruh indepedensi auditor terhadap kinerja auditor mendapatkan hasil dimana independensi berpengaruh positif dan signifikan terhadap kinerja auditor, hasil yang berbeda didapat oleh Bhagat \& Black (1998) yang menyatakan bahwa independensi berpengaruh negatif terhadap kinerja auditor.

Faktor lain yang juga penting dan dapat memengaruhi kinerja auditor yaitu pemahaman good governance. Good governance merupakan tata kelola yang baik pada suatu usaha yang dilandasi oleh etika profesional dalam berusaha/berkarya. Pemahaman good governance merupakan wujud penerimaan akan pentingnya suatu perangkat peraturan atau tata kelola yang baik untuk mengatur hubungan, fungsi dan kepentingan berbagai pihak dalam urusan bisnis maupun pelayanan publik (Suryadi, 2015). Pemahaman good governance merupakan wujud respek terhadap sistem dan struktur yang baik untuk mengelola perusahaan dengan tujuan meningkatkan produktivitas usaha. Trisnaningsih (2007) menyatakan good 
governance digunakan untuk mendorong kinerja perusahaan serta memberikan kepercayaan bagi pemengang saham dan masyarakat. Salah satu manfaat yang bisa dipetik dengan melaksanakan good governance adalah meningkatkan kinerja perusahaan melalui terciptanya proses pengambilan keputusan yang lebih baik, meningkatkan efisiensi operasional perusahaan serta lebih meningkatkan pelayanan kepada stakeholder (FCGI, 2000 dalam Trisnaningsih (2007)). Auditor yang memiliki pemahaman akan good governance yang baik akan melaksanakan pekerjaannya sesuai etika profesinya memberikan arahan jelas akan perilakunya. Pengimplementasian good governance akan mendongkrak auditor melaksanakan pengauditan dengan baik sehingga tercapai pula kinerja yang cemerlang. Penelitian-penelitian sebelumnya tentang hubungan pemahaman good governance terhadap kinerja auditor menyatakan hasil inkonsistensi dimana penelitian Trisnaningsih (2007), Yuskar \& Devisia (2011), dan Prajitno (2012) mendapatkan hasil pemahaman good governance tidak berpengaruh langsung pada kinerja auditor, hasil yang berbeda didapat oleh Wati et al. (2010) dan Suryadi (2015) yang menyatakan dimana pemahaman good governance berpengaruh positif terhadap kinerja auditor.

Selain independensi auditor dan pemahaman good governance, faktor self efficacy juga dapat memengaruhi kinerja auditor. Kepercayaan diri (Self efficacy) berhubungan dengan keyakinan individu mengenai kompetensi dan kemampuan dari seseorang (Kristiyanti, 2015). Self efficacy secara khusus dapat menunjukkan keyakinan auditor atas kemampuannya untuk menyelesaikan suatu tugas yang diberikan (Bandura, 1993). Individu-individu dengan tingkat self efficacy tinggi 
Ida Bagus Widya Kirana dan H. Bambang Suprasto. Pengaruh ...

akan merasa yakin terhadap kapabilitas kinerja mereka. Kristiyanti (2015) menyatakan faktor terpenting dalam self efficacy adalah pengalaman masa lalu. Jika pada suatu periode seorang auditor dapat menyelesaikan suatu tugas dan berhasil dalam kinerjanya, maka dia akan cenderung membangun rasa percaya diri dan keyakinan yang tinggi akan kemampuannya dalam menyelesaikan tugas secara sukses. Self efficacy dapat menjadi lemah apabila berulang kali gagal melaksanakan suatu tugas dengan baik.

Self-efficacy diturunkan dari teori kognitif social (sosial cognitif theory), hal tersebut dikemukakan oleh (Bandura, 1986). Secara singkat teori tersebut menyatakan, sebagian besar pengetahuan dan perilaku anggota organisasi digerakkan dari lingkungan, dan secara terus menerus mengalami proses berpikir terhadap informasi yang diterima. Hal tersebut mempengaruhi motivasi, sikap, dan perilaku individu. Beberapa penelitian menunjukkan bahwa self-efficacy memberi kontribusi signifikan pada pilihan tingkat tujuan individual (Locke \& Latham, 1990). Selanjutnya hubungan ini berdampak pada pencapaian tujuan dan akan berhubungan dengan kinerja (Locke \& Latham, 1990). Penelitian sebelumnya tentang pengaruh self efficacy terhadap kinerja auditor yang dilakukan oleh Kristiyanti (2015) memperoleh hasil bahwa self efficacy berpengaruh positif terhadap kinerja auditor. Hasil yang berbeda diperoleh Nadhiroh (2010) bahwa variabel self-efficacy tidak berpengaruh secara signifikan terhadap kinerja auditor.

Penelitian ini merupakan gabungan dari penelitian yang dilakukan oleh Wati et al. (2010) dan Dripani \& Pratomo (2014). Variable tersebut meliputi 
Independensi auditor dan pemahaman good governance yang diadopsi dari penelitian mereka. Perbedaan penelitian ini dengan penelitian sebelumnya adalah dengan menambahkan variabel Self efficacy. Perbedaan lainnya dari penelitian ini dengan penelitian sebelumnya adalah dari lokasi penelitian tersebut, dimana penelitian Wati et al. (2010) dilakukan di Badan Pengawasan Keuangan dan Pembangunan (BPKP) Perwakilan Bengkulu dan Dripani \& Pratomo (2014) di Badan Pengawas Keuangan (BPK) RI Perwakilan Provinsi Jawa Barat sedangkan penelitian ini berlokasi di KAP daerah Bali.

Organisasi perusahaan merupakan jaringan kontraktual antara prinsipal dan agen. Hubungan kontrak ini berupa pendelegasian wewenang oleh prinsipal (stake holders) kepada agen (manajemen), dimana agen bertugas untuk memaksimalkan kesejahteraan prinsipal. Namun, agen justru cenderung memaksimalkan kesejahteraannya sendiri dengan mengorbankan kepentingan pemegang saham. Hubungan ini juga menimbulkan pertanggungjawaban pihak manajemen kepada stake holders atas sumber aset dan aset yang mereka kelola. Kedua pihak ini memiliki kepentingan yang tentunya berbeda. Posisi, fungsi, situasi, tujuan, kepentingan dan latar belakang prinsipal dan agen yang berbeda akan menimbulkan pertentangan dengan saling tarik menarik kepentingan (conflict of interest) dan pengaruh antara satu sama lain. Konflik kepentingan muncul dalam suatu teori yang menyebutkan bahwa adanya hubungan antara pemegang saham (sebagai prinsipal) dan manajemen (sebagai agen). Teori ini dikemukakan oleh (Jensen and Meckling, 1976) yang disebut dengan teori keagenan. 
Ida Bagus Widya Kirana dan H. Bambang Suprasto. Pengaruh ...

Disebutkan dalam SA 200 menyebutkan bahwa sangat penting bagi seorang auditor untuk mempertahankan indepedensinya dalam melakukan pemeriksaan terhadap kewajaran laporan keuangan. Standar ini menjelaskan bahwa indepedensi didefinisikan sebagai sikap mental yang bebas dari pengaruh, tidak dikendalikan dari pihak lain dan tidak terantung pada orang lain yang berari ada kejujuran dalam diri auditor dalam mempertimbangkan fakta dan adanya pertimbangan yang objektif tidak memihak dalam merumuskan dan menyatakan pendapatnya.

Selain itu independensi adalah auditor berkewajiban untuk jujur tidak hanya pada manajemen perusahaan dan pemilik perusahaan, tetapi juga pada kreditur dan pihak lain yang meletakkan keperayaannya kepada mereka (Kharismatuti, 2012). Auditor secara intelektual harus jujur, bebas dari kewajiban terhadap klien, baik manajemen maupun pemilik perusahaan (Arumsari, 2014).

Good governance merupakan tata kelola yang baik pada suatu usaha yang dilandasi oleh etika profesional dalam berusaha/berkarya (Trisnaningsih, 2007). Good Governance juga dimaksudkan sebagai suatu kemampuan manajerial untuk mengelola sumber daya dan urusan suatu negara dengan cara-cara terbuka, transparan, akuntabel, equitable, dan responsif terhadap kebutuhan masyarakat (Widyananda, 2008). Trisnaningsih (2007) menyatakan pemahaman good governance merupakan wujud penerimaan akan pentingnya suatu perangkat peraturan atau tata kelola yang baik untuk mengatur hubungan, fungsi dan kepentingan berbagai pihak dalam urusan bisnis maupun pelayanan publik. Pemahaman atas good governance adalah untuk menciptakan keunggulan 
manajemen kinerja baik pada perusahaan bisnis manufaktur (good corporate governance) ataupun perusahaan jasa, serta lembaga pelayanan publik/pemerintahan (good government governance).

Penelitian Oktavia (2015) menemukan bahwa auditor harus memiliki sikap indepedensi yang artinya auditor harus memiliki sikap yang netral dan tidak bias serta menghindari konflik kepentingan dalam merencanakan, dalam melaksanakan audit. Independensi dapat juga diartikan adanya kejujuran dalam diri auditor dalam mempertimbangkan fakta dan adanya pertimbangan yang obyektif tidak memihak dalam diri auditor dalam merumuskan dan menyatakan pendapatnya (Mulyadi, 2002).

Dari hasil penelitian sebelumnya yang dilakukan oleh Yulistiyani (2014) dengan judul "Pengaruh Independensi Auditor, Gaya Kepemimpinan, Komitmen Organisasi Dan Budaya Organisasi Terhdap Kinerja Auditor (Studi Empiris Pada Kantor Akuntan Publik di Surakarta dan Yogyakarta) menunjukkan bahwa Indepedensi Auditor berpengaruh positif terhadap kinerja auditor. Penelitian lain yang dilakukan oleh Arifah (2012) dengan judul "Pengaruh Independensi Auditor, Komitmen Organisasi dan Gaya Kepemimpinan Terhadap Kinerja Auditor” juga menunjukkan bahwa Indepedensi Auditor berpengaruh positif dan signifikan terhadap kinerja auditor.

Hubungan antara independensi auditor dengan kinerja, bahwa seoarang auditor yang memiliki independensi yang tinggi maka dia tidak akan mudah terpengaruh dan tidak mudah dikendalikan oleh pihak lain dalam mempertimbangkan fakta yang dijumpai dalam pemeriksaan dan dalam 
Ida Bagus Widya Kirana dan H. Bambang Suprasto. Pengaruh ...

merumuskan dan menyatakan pendapatnya sehingga akan mempengaruhi tingkat pencapaian pelaksanaan suatu pekerjaan yang semakin baik atau dengan kata lain kinerjanya akan menjadi lebih baik. Berdasarkan uraian diatas, maka dapat dirumuskan hipotesis sebagai berikut.

$\mathrm{H}_{1}$ : Indepedensi Auditor berpengaruh positif pada kinerja auditor.

Trisnaningsih (2007) menyatakan pemahaman good governance merupakan wujud penerimaan akan pentingnya suatu perangkat peraturan atau tata kelola yang baik untuk mengatur hubungan, fungsi dan kepentingan berbagai pihak dalam urusan bisnis maupun pelayanan publik. Salah satu manfaat yang bisa dipetik dengan melaksanakan good governance adalah meningkatkan kinerja perusahaan melalui terciptanya proses pengambilan keputusan yang lebih baik, meningkatkan efisiensi operasional perusahaan serta lebih meningkatkan pelayanan kepada stakeholder (FCGI, 2000 dalam Trisnaningsih (2007)).

Hasil Penelitian sebelumnya yang dilakukan oleh Sitio (2014) mengenai "Pengaruh Pemahaman Good Governance, Gaya Kepemimpinan, Budaya Organisasi, Dan Struktur Audit terhadap Kinerja Auditor (Studi Empiris Pada Kantor Akuntan Publik di Kota Semarang)" menyatakan bahwa pemahaman good governance berpengaruh positif terhadap kinerja auditor. Penelitian lain yang dilakukan oleh Wati et al. (2010) mengenai "Pengaruh Independensi, Gaya Kepemimpinan, Komitmen Organisasi dan Pemahaman Good Governance Terhadap Kinerja Auditor Pemerintah (Studi Pada Auditor Pemerintah di BPKP Perwakilan Bengkulu)" menyatakan bahwa pemahaman good governance berpengaruh positif terhadap kinerja auditor. 
Auditor yang memiliki pemahaman akan good governance yang baik akan melaksanakan pekerjaannya sesuai etika profesinya memberikan arahan jelas akan perilakunya. Pengimplementasian good governance akan mendongkrak auditor melaksanakan pengauditan dengan baik sehingga tercapai pula kinerja yang cemerlang. Berdasarkan uraian diatas, maka dapat dirumuskan hipotesis sebagai berikut.

$\mathrm{H}_{2}$ : Pemahaman Good Governance berpengaruh positif pada kinerja auditor.

Bandura (1993) menyatakan bahwa self-efficacy adalah kepercayaan seseorang bahwa dia dapat menjalankan sebuah tugas pada sebuah tingkat tertentu, yang mempengaruhi aktifitas pribadi terhadap pencapaian tujuan. Kepercayaan diri atau self efficacy merupakan keyakinan individu terhadap kemampuan yang dimilikinya untuk memobilisasi motivasi, sumber daya kognitif dan tindakan-tindakan yang diperlukan atas situasi-situasi yang dihadapi (Bandura, 1986).

Hasil Penelitian sebelumnya yang dilakukan oleh Kristiyanti (2015) mengenai "Pengaruh Emotional Quotient Dan Self Efficacy Terhadap Kinerja Auditor (Studi Kasus Kantor Akuntan di Surakarta dan Yogyakarta)" menyatakan bahwa self efficacy berpengaruh positif dan signifikan terhadap kinerja auditor. Penelitian lain yang dilakukan oleh Gultom (2015) mengenai "Pengaruh Pengetahuan, Pengalaman Spesifik, dan Self Effiacy Terhadap kinerja Auditor Dengan Kompleksitas Tugas Sebagai Variabel Moderasi” yang menyatakan bahwa variabel self efficacy berpengaruh positif terhadap kinerja auditor.

Lee (2013) (dalam Kristiyanti (2015)) berargumen bahwa self efficacy 
mempunyai dampak yang signifikan terhadap kinerja auditor. Penelitian Kuang (2009) (dalam Kristiyanti (2015)) menunjukkan bahwa ada hubungan yang signifikan dan positif antara self efficacy dan keterlibatan kerja auditor. Auditor jika memiliki self efficacy yang tinggi akan dapat mengembangkan kepribadian yang kuat, mengurangi stress dan tidak mudah terpengaruh sehingga dapat melaksanakan kinerjanya dengan baik. Berdasarkan uraian diatas, maka dapat dirumuskan hipotesis sebagai berikut.

$\mathrm{H}_{3}$ : Self Efficacy berpengaruh positif pada kinerja auditor.

\section{METODE PENELITIAN}

Lokasi penelitian dalam penelitian ini dilakukan pada KAP di Bali yang tercatat di Directory Kantor Akuntan Publik. Alasan peneliti memilih KAP di Bali karena pengumpulan data pada penelitian ini dilakukan dengan metode survey dan pada saat pengiriman kuesioner peneliti ingin menyampaikannya sendiri kepada responden. Tujuannya adalah pertama, agar tingkat pengembalian (response rate) kuesioner yang telah diisi responden bisa lebih tinggi sehingga memenuhi target sampel minimal yang telah ditentukan. Kedua, peneliti dapat memahami (tahu persis) lokasi keberadaan KAP yang menjadi objek dalam penelitian ini. 
ISSN: 2302-8556

Tabel 1.

Indikator Pengukuran Variabel

\begin{tabular}{|c|c|c|}
\hline Variabel & Definisi & Indikator \\
\hline Independensi Auditor & $\begin{array}{l}\text { Independensi merupakan sikap } \\
\text { mental yang bebas dari pengaruh, } \\
\text { tidak dikendalikan oleh pihak lain, } \\
\text { tidak tergantung pada orang lain. }\end{array}$ & $\begin{array}{l}\text { - Indepedensi Penyusunan } \\
\text { Program } \\
\text { - Independensi investigatif } \\
\text { - Independensi pelaporan }\end{array}$ \\
\hline $\begin{array}{c}\text { Pemahaman Good } \\
\text { Governance }\end{array}$ & $\begin{array}{l}\text { Pemahaman good governance } \\
\text { merupakan wujud penerimaan akan } \\
\text { pentingnya suatu perangkat } \\
\text { peraturan atau tata kelola yang baik } \\
\text { untuk mengatur hubungan, fungsi } \\
\text { dan kepentingan berbagai pihak } \\
\text { dalam urusan bisnis maupun } \\
\text { pelayanan publik. }\end{array}$ & $\begin{array}{l}\text { - Prinsip keadilan } \\
\text { - Transparansi } \\
\text { - Akuntabilitas } \\
\text { - Pertanggungjawaban }\end{array}$ \\
\hline Self Efficacy & $\begin{array}{l}\text { Self-efficacy dinyatakan sebagai } \\
\text { kepercayaan seseorang bahwa dia } \\
\text { dapat menjalankan sebuah tugas } \\
\text { pada sebuah tingkat tertentu }\end{array}$ & $\begin{array}{l}\text { - Tingkat kesulitan tugas } \\
\text { - Keluasan bidang } \\
\text { pekerjaan } \\
\text { - Kekuatan terhadap } \\
\text { keyakinan }\end{array}$ \\
\hline Kinerja Auditor & $\begin{array}{l}\text { Kinerja auditor adalah akuntan } \\
\text { publik yang melakukan penugasan } \\
\text { pemeriksaan secara objektif atas } \\
\text { laporan keuangan suatu perusahaan }\end{array}$ & $\begin{array}{l}\text { - Kemampuan } \\
\text { - Komitmen profesi } \\
\text { - Motivasi } \\
\text { - Kepuasan kerja }\end{array}$ \\
\hline
\end{tabular}

Sumber: Data diolah, 2018

Populasi penelitian ini adalah seluruh auditor yang bekerja di Kantor Akuntan Publik di Provinsi Bali. Rincian auditor yang bekerja pada Kantor Akuntan Publik di Provinsi Bali disajikan dalan tabel 2 sebagai berikut:

Tabel 2.

Jumlah auditor pada Kantor Akuntan Publik di Bali Tahun 2018

\begin{tabular}{llc}
\hline No. & \multicolumn{1}{c}{ Nama Kantor Akuntan Publik } & Jumlah Auditor \\
\hline 1. & KAP I Wayan Ramantha & 9 \\
2. & KAP Johan Malonda Mustika \& Rekan (Cabang) & 5 \\
3. & KAP K. Gunarsa & 3 \\
4. & KAP Drs. Ketut Budiartha, Msi & 12 \\
5. & KAP Drs. Sri Marmo Djogosarkono \& Rekan & 18 \\
6. & KAP Drs. Wayan Sunasdyana & 11 \\
7. & KAP Drs. Ketut Muliartha RM \& Rekan & 8 \\
8. & KAP Budhananda Munidewi & 6 \\
9. & KAP Arnaya \& Darmayasa & 10 \\
10. & KAP Drs. Ida Bagus Djagera & - \\
11. & KAP Rama Wendra (Cab) & - \\
& Jumlah & 82 \\
\hline
\end{tabular}

Sumber: Data diolah, 2018 
Ida Bagus Widya Kirana dan H. Bambang Suprasto. Pengaruh ...

Teknik sampling jenuh yaitu teknik penentuan sampel dengan menggunakan semua anggota populasi sebagai sampel. Metode ini digunakan karena dipertimbangkan dari ketersediaan waktu dan jumlah yang memungkinkan untuk dilakukan penelitian secara keseluruhan. Responden yang digunakan sebagai sampel adalah sebanyak 82 auditor yang bekerja pada KAP di Wilayah Bali.

Uji hipotesis melalui teknik regresi linier berganda (multiple), adalah untuk mencari pengaruh Indepedensi Auditor $\left(\mathrm{X}_{1}\right)$, Pemahaman Good Governance $\left(\mathrm{X}_{2}\right)$, dan Self Efficacy $\left(\mathrm{X}_{3}\right)$ terhadap Kinerja Auditor $(\mathrm{Y})$. Model regresi linear ganda yang digunakan adalah dengan menggunakan rumus :

$$
\mathrm{Y}=\alpha+\beta_{1} \mathrm{X}_{1}+\beta_{2} \mathrm{X}_{2}+\beta_{3} \mathrm{X}_{3}+\mathrm{e}
$$

Keterangan :

$\begin{array}{ll}\mathrm{Y} & \text { : Kinerja Auditor } \\ \alpha & : \text { konstanta } \\ \mathrm{X} 1 & \text { : Indepedensi Auditor } \\ \mathrm{X} 2 & \text { : Pemahaman Good Governance } \\ \mathrm{X} 3 & \text { : Self Efficacy } \\ \beta_{1} & \text { : Koefisien regresi Indepedensi Auditor } \\ \beta_{2} & \text { : Koefisien regresi Pemahaman Good Governance } \\ \beta_{3} & \text { : Koefisien regresi Self Efficacy } \\ \mathrm{e} & \text { : Standar error }\end{array}$

\section{HASIL DAN PEMBAHASAN}

Statistik deskriptif memberikan informasi mengenai karakteristik variabelvariabel penelitian yang terdiri atas jumlah pengamatan nilai minimum, nilai maksimum, nilai mean, dan standar deviasi. Tabel 3 memerlihatkan hasil statistik deskriptif sebagai berikut. 
Tabel 3.

Hasil Statistik Deskriptif

\begin{tabular}{|c|c|c|c|c|c|}
\hline Variabel & $\mathrm{N}$ & Minimum & Maximum & Mean & Std. Deviation \\
\hline $\begin{array}{l}\text { Independensi } \\
\text { Auditor (X1) }\end{array}$ & 69 & 5,00 & 18,14 & 13,6677 & 4,61277 \\
\hline $\begin{array}{l}\text { Pemahaman Good } \\
\text { Governance (X2) }\end{array}$ & 69 & 8,00 & 32,13 & 23,6588 & 7,19093 \\
\hline Self Efficacy (X3) & 69 & 4,00 & 14,86 & 11,2039 & 3,76227 \\
\hline Kinerja Auditor (Y) & 69 & 7,00 & 31,48 & 22,0555 & 6,05905 \\
\hline
\end{tabular}

Sumber: Data diolah, 2018

Berdasarkan Tabel 3 diperoleh nilai terendah (minimum) dari jumlah skor jawaban responden untuk variabel Independensi Auditor $\left(\mathrm{X}_{1}\right)$ sebesar 5,00 dan nilai tertinggi (maximum) sebesar 18,14. Nilai tengah (mean) dari jumlah skor jawaban responden untuk variabel independensi auditor sebesar 13,6677, berarti jika jumlah skor jawaban responden lebih besar dari 13,677 maka termasuk pada responden yang memiliki tingkat independensi tinggi, dan sebaliknya. Nilai deviasi standar dari variabel independensi auditor adalah sebesar 4,61277 hal ini menunjukkan bahwa sebaran data condong ke kanan tetapi masih dalam batas normal.

Berdasarkan Tabel 3 diperoleh nilai terendah dari jumlah skor jawaban responden untuk variabel Pemaaman Good Governance sebesar 8,00 dan nilai tertinggi sebesar 32,13. Nilai tengah (mean) dari jumlah skor jawaban responden untuk variabel pemahaman good governance adalah sebesar 23,6588, hal ini berarti jika jumlah skor jawaban responden lebih besar dari 23,6588 maka termasuk pada responden yang memiliki pemahaman good governance tinggi, dan sebaliknya. Nilai deviasi standar dari variabel pemaaman good governance adalah sebesar 7,19093 hal ini menunjukkan bahwa sebaran data condong ke kanan tetapi masih dalam batas normal. 
Ida Bagus Widya Kirana dan H. Bambang Suprasto. Pengaruh ...

Berdasarkan Tabel 3 diperoleh nilai terendah dari jumlah skor jawaban responden untuk variabel self efficacy sebesar 4,00 dan nilai tertinggi sebesar 14,86. Nilai tengah (mean) dari jumlah skor jawaban responden untuk variabel self efficacy sebesar 11,2039, ini berarti jika jumlah skor jawaban responden lebih besar dari 11,2039 maka termasuk pada responden yang memiliki self eficcacy tinggi dan sebaliknya. Nilai deviasi standar dari variabel self efficacy adalah sebesar 3,76227 hal ini menunjukkan bahwa sebaran data condong ke kanan tetapi masih dalam batas normal.

Berdasarkan Tabel 3 diperoleh nilai terendah dari jumlah skor jawaban responden untuk variabel kinerja auditor sebesar 7,00 dan nilai tertinggi sebesar 31,48. Nilai tengah (mean) dari jumlah skor jawaban responden untuk variabel kinerja auditor sebesar 22,0555, hal ini berarti jika jumlah skor jawaban responden lebih besar dari 22,0555 maka termasuk pada responden yang memiliki kinerja audit tinggi dan sebaliknya. Nilai deviasi standar dari variabel kinerja auditor adalah sebesar 6,05905 hal ini menunjukkan bahwa sebaran data condong ke kanan tetapi masih dalam batas normal.

Hasil analisis regresi linear berganda disajikan pada Tabel 4 di bawah ini.

Tabel 4.

Hasil Analisis Regresi Linear Berganda

\begin{tabular}{|c|c|c|c|c|c|c|}
\hline \multirow{2}{*}{\multicolumn{2}{|c|}{ Model }} & \multicolumn{5}{|c|}{$\begin{array}{l}\text { Standardized } \\
\text { Coefficients }\end{array}$} \\
\hline & & B & Std. Error & Beta & $\mathbf{T}$ & Sig. \\
\hline \multirow[t]{4}{*}{1} & (Constant) & 5,138 & 1,736 & & 2,959 & ,004 \\
\hline & $\mathrm{X} 1$ &, 454 &, 140 & ,346 & 3,248 & ,002 \\
\hline & $\mathrm{X} 2$ & 245 & ,087 & 290 & 2,807 & ,007 \\
\hline & $\mathrm{X} 3$ & , 439 & 173 & ,272 & 2,537 &, 014 \\
\hline
\end{tabular}


Berdasarkan Tabel 4 dapat dibuat suatu model persamaan regresi linear berganda yaitu sebagai berikut.

$$
Y=5,138+0,454 X_{1}+0,245 X_{2}+0,439 X_{3}+e
$$

Nilai konstanta $(\alpha)$ sebesar 5,138 memiliki arti jika variabel Independensi Auditor (X1), Pemahaman Good Governance (X2) dan Self Efficacy (X dinyatakan konstan, maka Kinerja Auditor (Y) cenderung meningkat sebesar 5,138 satuan.

Nilai koefisien regresi $\left(\beta_{1}\right)$ pada variabel Independensi Auditor sebesar 0,454. Koefisien regresi yang bernilai positif memiliki arti jika variabel lainnya konstan sementara independensi auditor (X1) naik sebesar satu satuan, maka kinerja auditor (Y) akan meningkat sebesar 0,454 satuan.

Nilai koefisien regresi $\left(\beta_{2}\right)$ pada variabel pemahaman good governance sebesar 0,245. Koefisien regresi yang bernilai positif memiliki arti jika variabel lainnya konstan sementara variabel pemahaman good governance (X2) naik sebesar satu satuan, maka kinerja auditor (Y) akan akan meningkat sebesar 0,245 satuan.

Nilai koefisien regresi $\left(\beta_{3}\right)$ pada variabel self efficacy sebesar 0,439. Koefisien regresi yang bernilai positif memiliki arti jika variabel lainnya konstan sementara variabel self efficacy (X3) naik sebesar satu satuan, maka perilaku audit disfungsional (Y) akan akan meningkat sebesar 0,439 satuan.

Berdasarkan hasil olah data, maka hasil uji kelayakan model dapat disajikan pada Tabel 5 sebagai berikut 
Tabel 5.

Hasil Uji Kelayakan Model

\begin{tabular}{llrrrrr}
\hline Model & & Sum of Squares & Df & Mean Square & F & \multicolumn{1}{c}{ Sig. } \\
\hline 1 & Regression & 1538,719 & 3 & 512,906 & 34,811 &, $000^{\mathrm{b}}$ \\
& Residual & 957,700 & 65 & 14,734 & & \\
& Total & 2496,418 & 68 & & & \\
\hline
\end{tabular}

Sumber: Data diolah, 2018

Berdasarkan Tabel 5 hasil uji kelayakan model menunjukkan bahwa signifikansi $\mathrm{F}$ sebesar 0,000 lebih kecil dari 0,05, sehingga dapat disimpulkan bahwa model penelitian ini dikatakan layak untuk diteliti dan pembuktian hipotesis dapat dilanjutkan.

Hasil uji adjusted $\mathrm{R}^{2}$ disajikan pada Tabel 6 di berikut ini.

Tabel 6.

Hasil koefisien determinasi (adjusted $\mathbf{R}^{2}$ )

\begin{tabular}{lrrrr}
\hline Model & $\mathrm{R}$ & R Square & Adjusted R Square & $\begin{array}{c}\text { Std. Error of the } \\
\text { Estimate }\end{array}$ \\
\hline 1 &, $785^{\text {a }}$ &, 616 &, 599 & 3,83847 \\
\hline
\end{tabular}

Sumber: Data diolah, 2018

Berdasarkan Tabel 6, dapat diketahui nilai dari adjusted $\mathrm{R}^{2}$ adalah 0,599 atau 59,9 persen, ini artinya sebesar 59,9 persen variasi kinerja auditor dipengaruhi oleh model yang dibentuk oleh independensi auditor $\left(\mathrm{X}_{1}\right)$, pemahaman good governance $\left(\mathrm{X}_{2}\right)$ dan self efficacy $\left(\mathrm{X}_{3}\right)$, sedangkan sisanya sebesar 40,1 persen dijelaskan oleh faktor lain yang tidak dijelaskan dalam penelitian ini.

Berdasarkan hasil olah data, maka hasil uji statistik t dapat disajikan pada Tabel 7 sebagai berikut. 
Tabel 7.

Hasil Uji Statistik t

\begin{tabular}{llrrr}
\hline \multicolumn{1}{c}{ Model } & B & \multicolumn{1}{c}{ T } & \multicolumn{1}{c}{ Sig. } \\
\hline 1 (Constant) & 5,138 & 2,959 &, 004 \\
& Independensi auditor (X1) &, 454 & 3,248 &, 002 \\
& Pemahaman Good governance (X2) &, 245 & 2,807 &, 007 \\
Self Efficacy (X3) &, 439 & 2,537 &, 014 \\
\hline \multicolumn{2}{l}{ Sumber: Data diolah, 2018 } & &
\end{tabular}

Level of significant $(\alpha)$ yang digunakan adalah 5 persen $(0,05)$. Apabila $p$ value lebih besar dari nilai $\alpha=0,05$ maka $\mathrm{H}_{0}$ diterima atau $\mathrm{H}_{1}$ ditolak. Sebaliknya jika tingkat $\mathrm{p}$ value lebih kecil dari atau sama dengan $\alpha=0,05$ maka $\mathrm{H}_{0}$ ditolak atau $\mathrm{H}_{1}$ diterima.

Pada Tabel 7 dapat dilihat bahwa hasil uji statistik variabel independesi auditor diperoleh p value sebesar 0,002 dengan koefisien regresi sebesar 0,454. Berdasarkan hasil uji statistik tersebut, maka hipotesis 1 diterima atau independensi auditor berpengaruh positif pada kinerja auditor.

Pada Tabel 7 dapat dilihat bahwa hasil uji statistik variabel pemahaman good governance diperoleh $\mathrm{p}$ value sebesar 0,007 dengan koefisien regresi sebesar 0,245. Berdasarkan hasil uji statistik tersebut, maka hipotesis 2 diterima atau pemahaman good governance berpengaruh positif terhadap kinerja auditor.

Berdasarkan Tabel 7 diperoleh hasil uji statistik antara variabel self efficacy diperoleh $\mathrm{p}$ value sebesar 0,014 dengan koefisien regresi sebesar 0,439. Berdasarkan uji statistik tersebut maka hipotesis 3 diterima atau self efficacy berpengaruh positif terhadap kinerja auditor.

Hasil uji statistik variabel independensi auditor menunjukan hipotesis pertama $\left(\mathrm{H}_{1}\right)$ diterima. Artinya bahwa variable independensi auditor berpengaruh positif terhadap kinerja auditor. 
Ida Bagus Widya Kirana dan H. Bambang Suprasto. Pengaruh ...

Hasil penelitian ini konsisten dengan penelitian Awaluddin (2017) tentang pengaruh indepedensi auditor terhadap kinerja auditor mendapatkan hasil dimana independensi berpengaruh positif terhadap kinerja auditor. Hasil penelitian lain dari Yulistiyani (2014), Oktavia (2015), dan Wati et al. (2010) juga menunjukan hasil yang sama yaitu independensi auditor berpengaruh positif terhadap kinerja auditor.

Sehingga dapat disimpulkan terdapat hubungan antara independensi auditor dengan kinerja auditor, bahwa seorang auditor yang mempunyai independensi yang tinggi maka dia tidak akan mudah terpengaruh dan tidak mudah dikendalikan oleh pihak lain dalam mempertimbangkan fakta yang dijumpai dalam pemeriksaan dan dalam merumuskan dan menyatakan pendapatnya sehingga akan mempengaruhi kinerjanya menjadi lebih baik.

Hasil uji statistik variable pemahaman good governance menunjukan hipotesis kedua $\left(\mathrm{H}_{2}\right)$ diterima. Artinya bahwa variable pemahaman good governance berpengaruh positif terhadap kinerja auditor.

Penelitian-penelitian sebelumnya tentang hubungan pemahaman good governance terhadap kinerja auditor menyatakan hasil yang konsisten yaitu hasil yang didapat oleh Wati et al. (2010) dan Suryadi (2015) yang menyatakan dimana pemahaman good governance berpengaruh positif terhadap kinerja auditor.

Hal ini menunjukkan bahwa semakin paham seorang auditor terhadap good governance dalam bekerja maka akan semakin tinggi kinerja auditor tersebut. Seorang auditor yang memahami good governance secara benar dan bertanggungjawab maka akan mempengaruhi perilakunya dalam melaksanakan 
pekerjaannya dengan orientasi memperoleh hasil yang baik sehingga kinerjanya akan meningkat. Selain itu pemahaman prinsip keadilan, transparansi, akuntabilitas, dan pertanggungjawaban harus dipahami dalam meningkatkan kinerja auditor.

Hasil uji statistik variable self efficacy menunjukkan hipotesis ketiga $\left(\mathrm{H}_{3}\right)$ dapat diterima. Artinya bahwa variabel self efficacy berpengaruh positif terhadap kinerja auditor.

Penelitian sebelumnya tentang pengaruh self efficacy terhadap kinerja auditor yang dilakukan oleh Kristiyanti (2015) memperoleh hasil bahwa self efficacy berpengaruh positif terhadap kinerja auditor. Hasil yang sama diperoleh Afifah et al. (2015) dan Gultom (2015) yang menunjukan bahwa variabel selfefficacy berpengaruh positiv terhadap kinerja auditor.

Kondisi ini menggambarkan bahwa peningkatan self efficacy dari seorang auditor, akan meningkatkan kinerja dari auditor tersebut. Hal ini berarti bahwa auditor jika memiliki self efficacy/kepercayaan diri yang tinggi akan dapat mengembangkan kepribadian yang kuat, mengurangi stress dan tidak mudah terpengaruh sehingga dapat melaksanakan kinerjanya dengan baik.

Hasil penelitian ini memberikan tambahan informasi mengenai bagaimana pengaruh independensi auditor, pemahaman good governance, dan self efficacy terhadap kinerja auditor. Penelitian ini memberikan bukti empiris bahwa independensi auditor, pemahaman good governance, dan self efficacy dapat meningkatkan kinerja auditor. 
Ida Bagus Widya Kirana dan H. Bambang Suprasto. Pengaruh ...

Pada teori keagenan yang dikemukakan oleh (Jensen and Meckling, 1976) menjelaskan hubungan keagenan yang dimana terjadi suatu hubungan antara pemberi tugas (prinsipal) dan penerima tugas (agen). Seorang auditor yang bertindak sebagai agen mendapatkan pendelegasian wewenang dari prinsipal yang dimana dalam penelitian ini bertujuan untuk dapat mewujudkan kualitas audit yang baik. Hal ini dapat terwujud apabila seorang auditor memiliki independensi tinggi, pemahaman good governance yang baik, dan self efficacy yang tinggi untuk meningkatkan kinerja dari seorang auditor tersebut.

Hasil penelitian ini diharapkan mampu digunakan sebagai referensi, masukan, dan tambahan informasi bagi auditor yang bekerja di Kantor Akuntan Publik di Bali dalam meningkatkan kinerjanya dan hasil penelitian ini juga diharapkan dapat menjadi suatu dukungan terhadap terciptanya kualitas laporan audit yang lebih baik.

\section{SIMPULAN}

Independensi auditor berpengaruh positif terhadap kinerja auditor. Hal ini menunjukan bahwa seorang auditor yang mempunyai independensi tinggi maka dia tidak akan mudah terpengaruh dan tidak mudah dikendalikan oleh pihak lain dalam mempertimbangkan fakta yang dijumpai dalam pemeriksaan dan dalam merumuskan dan menyatakan pendapatnya sehingga akan mempengaruhi kinerjanya menjadi lebih baik. 
Pemahaman Good Governance berpengaruh positif terhadap kinerja auditor. Hal ini menunjukan bahwa semakin paham seorang auditor terhadap good governance dalam bekerja maka akan semakin tinggi kinerja auditor tersebut.

Self Efficacy berpengaruh positif terhadap kinerja auditor. Hal ini menunjukan bahwa auditor jika memiliki self efficacy/kepercayaan diri yang tinggi akan dapat mengembangkan kepribadian yang kuat, mengurangi stress dan tidak mudah terpengaruh sehingga dapat melaksanakan kinerjanya dengan baik.

Dilihat dari adjusted $R^{2}$ bahwa masih ada variabel lain yang mungkin dapat menjelaskan variabel yang memengaruhi kinerja auditor. Variabel lain yang dimaksud antara lain adalah tanggungjawab profesi, akuntabilitas, dan lain sebagainya.

Bagi pengelola KAP disarankan agar mengefektifkan pelaksanaan, mendukung serta memperhatikan tingkat independensi auditor dan pemahaman good governance dalam peningkatan kinerja auditor dan semua variabel bebas dalam penelitian ini disamping variabel-variabel lainnya yang berkontribusi meningkatkan kinerja auditor.

Bagi penelitian selanjutnya diharapkan dapat menambah variabel-variabel yang memiliki pengaruh terhadap kinerja auditor baik pengaruh positif maupun negatif seperti keahlian audit, gender, etika profesi, sikap skeptisme dan lain-lain.

Bagi penelitian selanjutnya diharapkan memperluas ruang lingkup sampel tidak hanya auditor yang bekerja di KAP namun juga auditor yang bekerja di BPK (Badan Pemeriksa Keuangan). 


\section{REFERENSI}

Afifah, U., Sari, R. N., Anugerah, R., \& Sanusi, Z. M. (2015). The Effect of Role Conflict , Self-efficacy, Professional Ethical Sensitivity on Auditor Performance with Emotional Quotient as Moderating Variable. Procedia Economics and Finance, 31(December), 206-212. https://doi.org/10.1016/S2212-5671(15)01222-8

Arianti, H. (2015). Faktor-fakktor yang Mempengaruhi Kinerja Auditor. (Studi Empiris Pada KAP di Surakarta Dan Yogyakarta). Universitas Muhammadiyah Surakarta.

Arifah, N. (2012). Pengaruh Independensi Auditor, Komitmen Organisasi dan Gaya Kepemimpinan Terhadap Kinerja Auditor. Universitas Hasanuddin.

Arumsari, A. L. (2014). Pengaruh Profesionalisme Auditor, Independensi Auditor, Etika Profesi, Budaya Organisasi, dan Gaya Kepemimpinan terhadap Kinerja Auditor pada Kantor Akuntan Publik Bali. Universitas Udayana.

Awaluddin, M. (2017). Pengaruh Independensi Dan Kompetensi Auditor Terhadap Kepuasan Kerja Dan Kinerja Auditor Inspektorat Kota Makassar. Jurnal Publikasi, Assets, (December). https://doi.org/10.13140/RG.2.2.35127.83368

Bandura, A. (1986). Social Foundatioan of Thouhgt and Action: a Social. Cognitive Theory. New Jersey: Prentice_Hall, Inc.

Bandura, A. (1993). Perceived Self-Efficacy in Cognitive Development and Functioning. Educational Psychologist, 28(2), 17-148.

Bhagat, S., \& Black, B. S. (1998). Bhagat, S. Black, B. SSRN Electronic Journal, 27(1). https://doi.org/10.2139/ssrn.133808

Dripani, M. E., \& Pratomo, D. (2014). Pengaruh Independensi, Penerapan Teknologi Informasi, dan Pemahaman Good Governance terhadap Kinerja Auditor (Studi Kasus Pada Auditor di BPK RI Perwakilan Provinsi Jawa Barat). Repository Jurnal Fakultas Ekonomi Unjani, 1-11.

Gultom, Y. (2015). Pengaruh Pengetahuan, Pengalaman Spesifik, dan Self Effiacy Terhadap kinerja Auditor Dengan Kompleksitas Tugas Sebagai Variabel Moderasi. Jurnal TEKUN, VI(01), 36-53.

Herawaty, A., \& Susanto, Y. K. (2009). Pengaruh Profesionalisme, Mendeteksi kekeliruan, dan Etika Profesi Terhadap Pertimbangan TingkatMaterialitas Akuntan Publik. Trisakti School of Management. 
Jensen, \& Meckling. (1976). The Theory of The Firm: Manajerial Behaviour, Agency Cost, and Ownership Structure. Journal of Financial and Economics, 3, 3025-3360.

Kharismatuti, N. (2012). Pengaruh Kompetensi dan Independensi Auditor Terhadap Kualitas Audit dengan Etika Auditor Sebagai Variabel Pemoderasi. Universitas Diponegoro.

Kristiyanti, L. M. S. (2015). Pengaruh Emotional Quotient dan Self Efficacy terhadap Kinerja Auditor (Studi Kasus Kantor Akuntan di Surakarta dan Yogyakarta). Jurnal Akuntansi Dan Pajak, 16(01), 88-102.

Locke, E. A., \& Latham, G. P. (1990). A theory of goal setting and task performance. Englewood Cliffs, NJ: Prentice Hall.

Mangkunegara, A. . . A. P. (2010). anajemen Sumber daya Manusiaperusahaan. Bandung: PT Remaja Rosdakarya.

Mulyadi. (2002). Auditing (6th ed.). Jakarta: Salemba Empat.

Mulyadi. (2014). Sistem Akuntansi (4th ed.). Jakarta: Salemba Empat.

Nadhiroh, S. A. (2010). Pengaruh Kompleksitas Tugas, Orientasi Tujuan, Dan Self Efficacy Terhadap Kinerja Auditor Dalam Pembuatan Audit Judgment (Studi Pada Kantor Akuntan Publik di Semarang). Universitas Diponegoro.

Oktavia, I. (2015). Pengaruh Indepedensi Auditor, Profesionalisme, Dan Etika Profesi Terhadap Kinerja Auditor Eksternal pada Kantor Akuntan Publik Di Wilayah Jakarta Timur. Universitas Darma Persada.

Prajitno, S. (2012). Faktor Faktor yang Mempengaruhi Kinerja Akuntan Publik di Jakarta. Jurnal Bisnis Dan Akuntansi, 14(3), 181-192.

Rangkuti, S. (2008). Auditing. (Andi, Ed.). Surabaya.

Santoso, K. (2002). Dampak Kebangkrutan Enron terhadap Citra Profesi Akuntan Publik. Media Akuntansi, 25(17).

Simamora, H. (1995). Manajemen Sumber Daya Manusia. Yogyakarta: STIE YKPN.

Sitio, R. (2014). Pengaruh Pemahaman Good Governance, Gaya Kepemimpinan, Budaya Organisasi Dan Struktur Audit Terhadap Kinerja Auditor (Studi Empiris Pada Kantor Akuntan Publik Di Kota Semarang). Accounting Analysis Journal, 3(3). https://doi.org/10.15294/aaj.v3i3.4198 
Suryadi. (2015). Pengaruh Indepedensi, Gaya Kepemimpinan, Komitmen Organisasi, Dan Pemahaman Good Governance Terhadap Kinerja Auditor Pemerintah (Studi Empiris pada Kantor BPKP Perwakilan Yogyakarta). Universitas Muhammadiyah.

Trisnaningsih, S. (2007). Independensi auditor dan komitmen organisasi sebagai mediasi pengaruh pemahaman. Simposium Nasional Akuntansi $X$. https://doi.org/10.1590/S0104-14282003000200006

Wati, E., Lismawati, \& Aprilla, N. (2010). Pengaruh Independensi, Gaya Kepemimpinan, Komitmen Organisasi, Dan Pemahaman Good Governance Terhadap Kinerja Auditor Pemerintah (Studi Pada Auditor Pemerintah di BPKP Perwakilan Bengkulu). Simposium Nasional Akuntansi XIII.

Widyananda, H. (2008). Revitalisasi Peran Internal Auditor Pemerintah Untuk Penegakan Good Governance di Indonesia. Universitas Padjadjaran.

Wirawan. (2009). Evaluasi Kinerja Sumber Daya Manusia: Teori Aplikasi dan Penelitian. Jakarta: Salemba Empat.

Yulistiyani, N. (2014). Pengaruh Independensi Auditor, Gaya Kepemimpinan, Komitmen Organisasi Dan Budaya Organisasi Terhdap Kinerja Auditor (Studi Empiris Pada Kantor Akuntan Publik di Surakarta dan Yogyakarta). Universitas Muhammadiyah Surakarta.

Yuskar, H., \& Devisia., S. (2011). Pengaruh Independensi Auditor, Komitmen Organisasi, Pemahaman Good Governance, Integritas Auditor, Budaya Organisasi, dan Etos Kerja Terhadap Kinerja Auditor. Jurnal Simposium Nasional Akuntansi XIV. 